\title{
MOLECULAR DETECTION OF SOME VIRULENCE GENES OF E.COLI ISOLATES FROM MEAT AND MEAT PRODUCT IN PORT-SAID GOVERNORATE
}

\author{
HANAN, A. ELGHAYATY ${ }^{1}$; AMAL, A.M. ${ }^{2}$ AND HELAL, I.M. ${ }^{1}$ \\ ${ }^{1}$ Food Hygiene Department, Animal Health Research Institute, Agriculture Research Center, \\ Port-Said Branch, Egypt \\ ${ }^{2}$ Bacteriology Department, Animal Health Research Institute, Agriculture Research Center, \\ Port-Said Branch, Egypt
}

Received: 26 July 2020; Accepted: 31 August 2020

\begin{abstract}
Food stuffs of animal origin may present hazards, due to bacterial contamination. This study was conducted to determine the prevalence, serotypes, and virulence genes of Escherichia coli in raw beef meat and some of meat products (raw, minced meat, beef burger and sausage, 25 sample each). Bacteriological examination of total 100 samples were collected from different localities in port-said City showed that 10/100 (10\%) of samples were infected with E. coli. The prevalence of E.coli strains in fresh and minced meat, beef burger and sausage samples were $4 \%(1 / 25), 16 \%(4 / 25), 8 \%(2 / 25)$, and $12 \%(3 / 25)$, respectively. Serological typing were conducted on 10 isolates and results obtained revealed that two (20\%) O114, $2(20 \%)$ O157, three (30\%) O125, and one (10\%) for each of O127; O18, and O158. Ten isolates were submitted to molecular studies for detection of the traT (transfer protein), iutA (encoding aerobactin) and iss (increased serum survival protein) genes, by using PCR technique. PCR assays for different virulence genes showed that sex (60\%), four (40\%), and sex (60\%) strains carry iss, iutA, and Trat genes, respectively.
\end{abstract}

Keywords: E.coli, virulence genes, Meat, Meat Products, PCR.

\section{INTRODUCTION}

Meat and its products as essential for human survival, it also essential for microorganisms to grow and thrive as raw meat and meat products still threaten human health via harboring pathogenic and zoonotic E. coli, (Karmi 2019). Therefore, the protection of human health is important to understand the microbial hazards in foods. $E$. coli are found in warm-blooded species including humans as part of the normal intestinal flora (FSANZ, 2013, Sarwska

Corresponding author: Hanan, A. Elghayaty E-mail address: hananelghayaty9866@gmail.com Present address: Food Hygiene Department, Animal Health Research Institute, Port-Said Branch, Egypt et al., 2019). They are facultative anaerobic, rod-shaped Gram-negative, bacteria it can grow at temperatures ranging between 7 $46^{\circ} \mathrm{C}$, pH of $4.4-10.0$ and a minimum water activity of 0.95 when other conditions are near optimum (FSANZ 2013). There are over 160 serological types of $E$. coli which are involved in urinary tract infection, pneumonia, sepsis, surgical infection, gastrointestinal tract infections, hemolyticuremic syndrome (HUS), and meningitis (Alkeskas et al., 2015). Although E. coli induced illness is much lower than that of other foodborne pathogens the severity of symptoms and the infectious dose made $E$. coli one of the most significant pathogens of public health importance, (Buncic, 2006, Lacher et al., 2016). The Contamination may 
occur directly through animal feces or indirectly through employees or contaminated working aids (Gyles, 2007, Darwish et al., 2018).

Meanwhile, the use of proper hygienic measures in handling food of animal origin and proper handling during processing and good heating before consumption are important control measures for the prevention of E. coli infections (Michael, 1991). Much is now known about the characteristics of this organism as it can survive in ground beef at $-20^{\circ} \mathrm{C}$ for nine months. The organism is heat sensitive, Proper cooking temperatures of $71^{\circ} \mathrm{C}$ will destroy the organism in foods. And it is quite salt tolerant, with the ability to grow at $8 \%$ $\mathrm{NaCl}$ at $37^{\circ} \mathrm{C}$; however, at a lower incubation temperature of $10^{\circ} \mathrm{C}$, growth was inhibited from $4 \%$ to $6 \%$. (Toldrá, 2010).

Processed meats and ready-to-eat food supply the increasing demand for meals prepared simply and quickly, in developed countries, people today are less prepared to spend the time required to cook a traditional meat meal, especially during the week. In addition to the effects of consumers' preferences, another force driving processed meats supply is their higher economic value (Wood, 2006). Meat products could be contaminated with pathogenic microorganisms from meat handlers during the processes of manufacturing, packing and marketing (Darwish et al., 2018). Improper cooking, refrigeration or storage may lead to meat borne illness. Food-borne pathogens are the leading causes of illness and death in developing countries costing billions of dollars in medical care, medical and social costs (Fratmico et al., 2005). On the other hand, the combination of salt and nitrites which used in many meat products may have an inhibitory effect on E. coli, (Casey and Condon, 2000).

The gaining of virulence genes is believed to provide an evolutionary pathway to pathogenicity, most strains of Escherichia coli are harmless commensals of mammals (Selander, R. K. et al., 1987), but others are capable of causing either intestinal or extraintestinal disease (Orskov, F. and Orskov, I., 1992). Manifestation of clinical symptomology and pathology appears to be closely associated with the possession of certain virulence gene combinations in $E$. coli (Grauke, L.J., 2002). The virulence factors, such as adhesions, invasions, toxins, iron acquisition systems (siderophores), and protectins, are involved in colonization, adhesion, invasion, and survival against host defenses (Janßen et al., 2001; Jeong et al., 2012 and Navaro-Garsia et al., 2019).

Therefore the present study was planned to detect the prevalence of E.coli in examined meat and some meat products, and detection of virulence genes in the isolates by using polymerase chain reaction (PCR).

\section{MATERIALS AND METHODS}

\section{1-Collection of samples:}

One hundred random samples of meat and meat by products as, minced meat, sausage and beef burger were randomly collected from markets in Port Said governorate. The collected samples were taken aseptically and transferred immediately to the laboratory in the (Department of Microbiology Port-Said lab). All samples were examined bacteriologically for detection of E.coli

\section{2-Isolation and identification of $\boldsymbol{E}$. coli:}

The standard protocol described by (APHA, 2001) was adopted for the isolation of E.coli from meat samples by add $25 \mathrm{~g}$ of each sample to $225 \mathrm{~mL}$ of buffered peptone water. This mixture was incubated at $37^{\circ} \mathrm{C}$ for 18- 24 hours, the enrichment cultures were streaked on Eosin Methylene Blue (EMB) (Oxoid), $37^{\circ} \mathrm{C}$ for $18-24 \mathrm{~h}$, typical E. coli colonies were picked and inoculated in Nutrient agar for purification, identification, and serotyping. 


\section{3- Detection of virulence genes:}

Is performed at (Reference laboratory for veterinary quality control on poultry production, Animal Health Research Institute) according to Yaguchi et al. (2007) and Kaipainen et al. (2002) as show in table (1)

DNA extraction: from samples was performed using the QIAamp DNA Mini kit (Qiagen, Germany, GmbH) with modifications from the manufacturer's recommendations. Briefly, $200 \mu \mathrm{l}$ of the sample suspension was incubated with $10 \mu \mathrm{l}$ of proteinase $\mathrm{K}$ and $200 \mu \mathrm{l}$ of lysis buffer at $56^{\circ} \mathrm{C}$ for $10 \mathrm{~min}$. After incubation, $200 \mu \mathrm{l}$ of $100 \%$ ethanol was added to the lysate. The sample was then washed and centrifuged following the manufacturer's recommendations. Nucleic acid was eluted with $100 \mu 1$ of elution buffer provided in the kit.
Oligonucleotide Primer: Primers used were supplied from Metabion (Germany) are listed in table (1).

PCR amplification: Primers were utilized in a 25- $\mu$ l reaction containing $12.5 \mu \mathrm{l}$ of Emerald Amp Max PCR Master Mix (Takara, Japan), $1 \mu \mathrm{l}$ of each primer of 20 pmol concentration, $4.5 \mu 1$ of water, and $6 \mu 1$ of DNA template.

Analysis of the PCR Products. The products of PCR were separated by electrophoresis on $1 \%$ agarose gel (Applichem, Germany, GmbH) in 1x TBE buffer at room temperature using gradients of $5 \mathrm{~V} / \mathrm{cm}$. For gel analysis, $20 \mu 1$ of the PCR products were loaded in each gel slot. Gelpilot 100 bp DNA Ladder (Qiagen, Germany, GmbH) was used to determine the fragment sizes. The gel was photographed by a gel documentation system (Alpha Innotech, Biometra) and the data was analyzed through computer software.

Table 1: Primers sequences, target genes, amplicon sizes and cycling conditions.

\begin{tabular}{|c|c|c|c|c|c|c|c|c|}
\hline \multirow[t]{2}{*}{$\begin{array}{l}\text { Target } \\
\text { gene }\end{array}$} & \multirow[t]{2}{*}{$\begin{array}{c}\text { Primers } \\
\text { sequences }\end{array}$} & \multirow[t]{2}{*}{$\begin{array}{c}\text { Amplified } \\
\text { segment (bp) }\end{array}$} & $\begin{array}{c}\text { Primary } \\
\text { Denaturation }\end{array}$ & \multicolumn{3}{|c|}{ Amplification (35 cycles) } & \multirow[t]{2}{*}{$\begin{array}{c}\text { Final } \\
\text { extension }\end{array}$} & \multirow[t]{2}{*}{ Reference } \\
\hline & & & & $\begin{array}{c}\text { Secondar } \\
\text { denaturation }\end{array}$ & Annealing & Extension & & \\
\hline Iss & $\begin{array}{c}\text { ATG TTA } \\
\text { TTT TCT } \\
\text { GCC GCT } \\
\text { CTG }\end{array}$ & 266 & $\begin{array}{l}94^{\circ} \mathrm{C} \\
5 \mathrm{~min} .\end{array}$ & $\begin{array}{c}94^{\circ} \mathrm{C} \\
30 \mathrm{sec} .\end{array}$ & $\begin{array}{c}54^{\circ} \mathrm{C} \\
30 \mathrm{sec} .\end{array}$ & $\begin{array}{c}72^{\circ} \mathrm{C} \\
30 \mathrm{sec} .\end{array}$ & $\begin{array}{l}72^{\circ} \mathrm{C} \\
7 \mathrm{~min} .\end{array}$ & $\begin{array}{c}\text { Yaguchi } \\
\text { et al., } \\
2007\end{array}$ \\
\hline 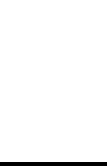 & $\begin{array}{c}\text { CTA TTG } \\
\text { TGA GCA } \\
\text { ATA TAC } \\
\text { CC } \\
\end{array}$ & & & & & & & \\
\hline iutA & $\begin{array}{c}\text { GGCTGGAC } \\
\text { ATGGGAAC } \\
\text { TGG }\end{array}$ & 300 & & & $\begin{array}{c}63^{\circ} \mathrm{C} \\
30 \mathrm{sec} .\end{array}$ & & & \\
\hline & $\begin{array}{c}\text { CGTCGGGA } \\
\text { ACGGGTAG } \\
\text { AATCG }\end{array}$ & & & & & & & \\
\hline TraT & $\begin{array}{c}\text { GATGGCTG } \\
\text { AACCGTGG } \\
\text { TTATG }\end{array}$ & 307 & & & $\begin{array}{c}55^{\circ} \mathrm{C} \\
30 \mathrm{sec} .\end{array}$ & & & $\begin{array}{c}\text { Kaipain } \\
\text { en } \text { et al., } \\
2002\end{array}$ \\
\hline & $\begin{array}{c}\text { CACACGGG } \\
\text { TCTGGTAT } \\
\text { TTATGC }\end{array}$ & & & & & & & \\
\hline
\end{tabular}




\section{RESULTS}

E. coli is a Gram negative, rod shaped bacteria under microscope, facultative anaerobic bacteria. On Eosin Methylene Blue colonies are metallic sheen green colonies. Several biochemical tests used for biochemical identification, It was positive for Indole, Methyle red, nitrate reduction, catalase, and negative for Oxidase, Urease, $\mathrm{H} 2 \mathrm{~S}$, Simmon`s citrate, Voges- Proskauer, and gelatin liquefaction. E.coli ferment lactose and glucose with acid and gas production. E.coli was isolated from meat $(1 / 25,4 \%)$, minced meat $(4 / 25,16 \%)$, sausage $(3 / 25,12 \%)$ and beef burger $(2 / 25$, $8 \%)$. The total percentage of positive samples was $10 \%$. The highest isolation percentage was from minced meat $(16 \%)$ and the lowest percentage was from raw meat (4\%). As shown in Table (2). Ten E.coli isolates were recovered from a total of 100 samples (meat, minced meat, sausage and beef burger) 25 each.

Table 2: Prevalence of E. coli in meat and meat products.

\begin{tabular}{ccccc}
\hline \multirow{2}{*}{ Type of samples } & $\begin{array}{c}\text { Number of } \\
\text { samples }\end{array}$ & No. & $\begin{array}{c}\mathbf{\%} \\
\mathbf{N = 2 5}\end{array}$ & $\begin{array}{c}\text { \%** } \\
\mathbf{N = 1 0 0}\end{array}$ \\
\cline { 2 - 5 } Meat & 25 & 1 & 4 & 1 \\
\hline Minced meat & 25 & 4 & 16 & 4 \\
\hline Sausage & 25 & 3 & 12 & 2 \\
\hline Beef burger & 25 & 2 & 8 & 10 \\
\hline Total & 100 & 10 & 40 & 2 \\
\hline *No. of isolates/ no. of samples. & $* *$ No. of isolates/ total no. of samples.
\end{tabular}

Table 3: Serological identification of isolated E. coli from meat and meat products.

\begin{tabular}{cc}
\hline E.coli isolates & monovalent \\
\hline Meat & O18 \\
\hline Minced meat & O114 \\
\hline Minced meat & O158 \\
\hline Minced meat & O127 \\
\hline Minced meat & O125 \\
\hline Sausage & O157 \\
\hline Sausage & O157 \\
\hline Sausage & O125 \\
\hline Beef burger & O114 \\
\hline Beef burger & O125
\end{tabular}

Ten E.coli isolates were submitted to serology unit - Animal Health Research Institute, for serological identification. The one E.coli isolate of meat was belonging to O18, the four E.coli isolates of minced meat were serotyped as O114, O158, O127 and O125, while the three E.coli isolates of sausage were $\mathrm{O} 157, \mathrm{O} 157$ and $\mathrm{O} 125$. The two E.coli isolates recovered from beef burger were $\mathrm{O} 114$ and $\mathrm{O} 125$, as shown in (Table 3).

Isolated E.coli (ten isolates) were submitted for molecular detection and determination of virulence genes: the Increased Serum Survival gene (iss), the Iron Uptake gene (iutA) and surface exclusion protein gene (traT) by RT-PCR, (Table 4). Figures (1, 2 
and 3).The results showed that, iss gene was detected in $6 \mathrm{E}$-coli isolates, one from meat isolate, two form minced meat isolates, two from sausage isolates and one from beef burger. iutA gene was detected in $4 \mathrm{E}$-coli isolates, two from minced meat and two from sausage. traT gene was detected in 6 isolates, two from minced meat, two from sausage and two from beef burger, (Table 4).

Table 4: Prevalence of virulence genes (iss, iutA and traT) in E-coli isolates:

\begin{tabular}{|c|c|c|c|c|}
\hline \multirow{2}{*}{ E-coli Isolate } & \multirow{2}{*}{ Source } & \multicolumn{3}{|c|}{ Results } \\
\hline & & $I s S$ & $\overline{\text { iutA }}$ & traT \\
\hline 1 & Meat & + & - & - \\
\hline 2 & Minced meat & - & - & - \\
\hline 3 & Minced meat & - & - & - \\
\hline 4 & Minced meat & + & + & + \\
\hline 5 & Minced meat & + & + & + \\
\hline 6 & Sausage & + & + & - \\
\hline 7 & Sausage & + & + & + \\
\hline 8 & Sausage & - & - & + \\
\hline 9 & Beef burger & + & - & + \\
\hline 10 & Beef burger & - & - & + \\
\hline
\end{tabular}

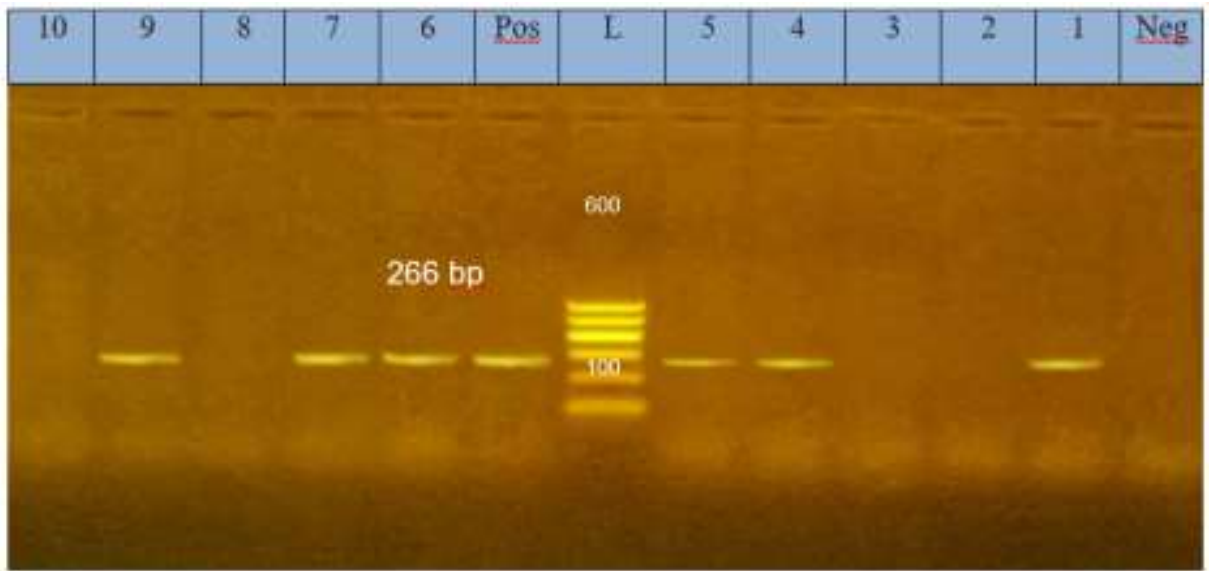

Fig. (1): Agarose gel electrophoresis of amplified iss gene PCR product (266 bp).

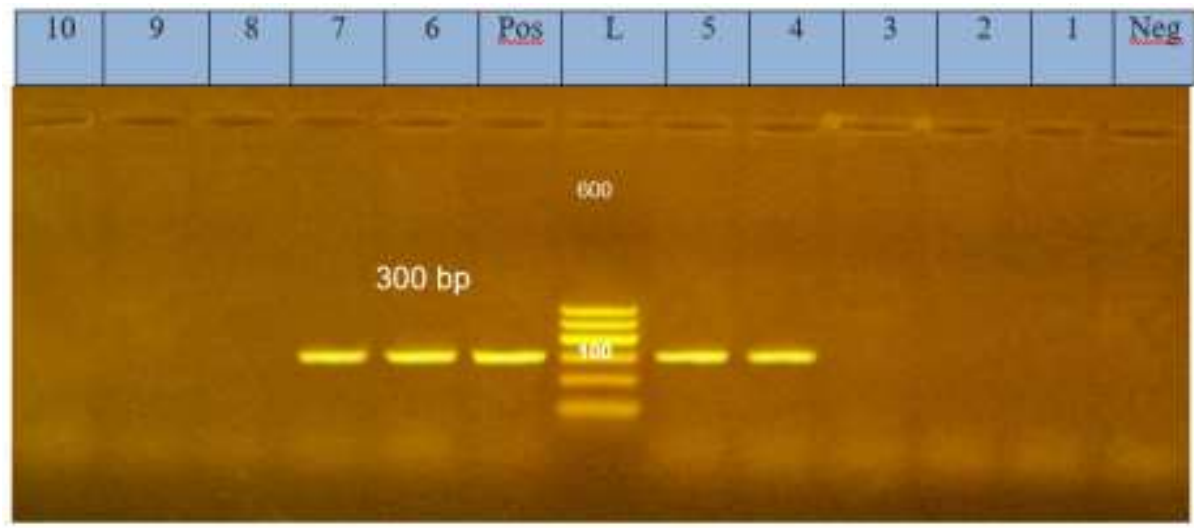

Fig. (2): Agarose gel electrophoresis of amplified iutA gene PCR product (300 bp). 


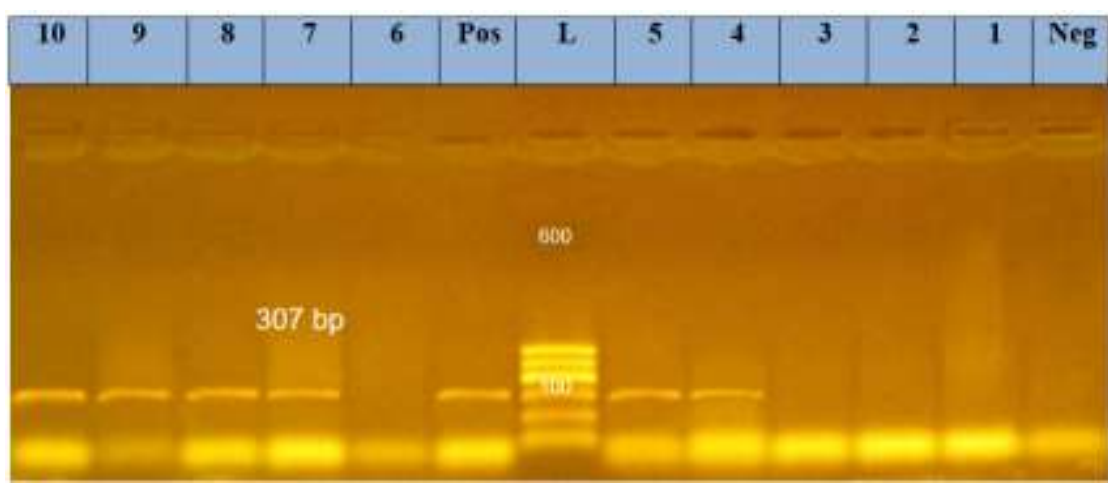

Fig. (3): Agarose gel electrophoresis of amplified traT gene PCR product (307 bp).

\section{DISCUSSION}

In the last years and due to great development in human life caused a great demined of easily prepared meals contained high level of animal protein. So meat and meat products are good source of protein contain an essential amino acids (Bieslski, 2005). The incidence of E.coli in the present study in table (2) show that ten isolate from 100 sample $10 \%$ positive of E,coli in meat and meat by product (minced meat, sausage, beef burger) which similar to Mohamed (2012) (9.3\%) but less than obtained by Eid et al. (2019) in Port-Said who found it $43 \%$ the incidence of E.coli in fresh meat sample $(4 \%)(1 / 25)$ which similar to Sallam et al. (2013) (3.7\%) this result less than obtained by Zohreh Mashak (2018) and Ateba \& Mbewe (2011) who found that the percentage of $E$. coli in meat are $14 \%$ and $27 \%$ respectively. Unlike fresh beef, which showed low prevalence for $E$. coli a higher contamination rate of $16 \%(4 / 25)$ was detected in the ground beef analyzed. In a previous study from Egypt, Abdul-Raouf et al. (1996) detected $E$. coli in ground beef at a lower occurrence of $6 \%$ (3/50)but our result similar with obtained by Ibrahim et al. (2015) and less than Zakarya and Fouad (2013) who found E.coli in minced meat $25 \%$. regard to E.coli in beef burger $2 / 25$ (8\%)which nearly similar to obtained by Ahmed (1992), and EL-sherif (2009) who recorded the incidence of E.coli as $6.6 \%$ and $10 \%$ and less than obtained by Ibrahim et al. (2015) which found E. coli in beef burger as $24 \%$ in regarded to sausage the incidence was $2 \%$ which nearly similar to obtained by Zakarya and Fouad (2013) and Ahmed (1992) were $16.6 \%$ and $15 \%$ respectively and lower than obtained by Ibrahim et al. (2015) and EL-Mossalami (2003) were 44\% and $40 \%$ respectively. The higher contamination rate of $E$. coli strains in ground beef, sausage and beef burger samples in comparison to fresh beef samples in this study may be attributed to the fact that these products needs production process which may lead to contamination.

Out of 10 E. coli strains, only 6 were serotyped by using commercially available antisera as shown in Table (3). Distribution of $6 \mathrm{E}$. coli serotypes recovered from meat, minced meat, Sausage and beef burger were belonged to (O18, O114, O158, O127, O125, and O157) Similar findings have been reported by (Ibrahim et al., 2015) who isolated E. coli $\mathrm{O} 114$, and $\mathrm{O} 125$ from meat, minced meat, burger and sausage, (Seran et al., 2012) isolated O:157 K:- serotype from meat. Also Eid et al. (2019) isolated O114, O158, O127, O125. Karmi (2019) O157, O127, O125 from meat and its products. The most important E.Coli serotypes which have been associated with human illness are O157, O111, O26, O103, O113, O91, O117, O118, O121, O145, O128, and O146 (Rahal et al., 2015), while Kaper 1994 proved that $\mathrm{O} 125$ and $\mathrm{O} 127$ are usually transmitted by contaminated food and colonize the small intestine where they attach tightly to the epithelial cells of the villus tips and cause typical lesions called attaching and effacing lesions. 
The difference in the rate of isolation of $E$. coli and its serotypes may attribute to difference in localities, methods of sampling and total number of samples. Also the variation in the results obtained by different investigators may be due to difference in manufacturing practices, handling and difference in time while Undercooked meat products have caused many food poisoning incidents associated with $E$. coli which is present in the faces, intestines and hide of healthy cattle from where it can potentially contaminate meat during the slaughtering process (Duffy et al., 2003, Darwish et al., 2018). Enterobacteriaceae were very useful as indicators of bad hygiene or bad treatment of food products and their presence in large number indicates a big possibility of the multiplication of E.coli and other pathogens (Nissen et al., 2001).

While E. coli serotyping is an important technique for making the proper diagnosis and epidemiological investigations during foodborne outbreaks, it cannot be relied on alone for categorizing a strain of E. coli, so the identification of specific virulence genes must also be performed (Barlow et al., 1999). PCR is a powerful molecular biology technique for the detection of virulence genes, it is not only highly sensitive and specific, but it also provides rapid and reliable results (Abdeltawab 2015). It can help to distinguish $E$. coli isolates from meat and meat products through detection of virulence genes (Kimata et al., 2005). Our study revealed that iss gene was detected in $6 / 10(60 \%) E$. coli isolates while the highest result $100 \%$ recorded by Jørgensen et al. (2019), Oliveira et al. (2019) and Marwa Hassan et al. (2020) and the lowest 20\%, 15.2 and 31.8 recorded by, Cyoia et al. (2015) and Bok et al. (2020) respectively. In the present work, it was found that the prevalence rate of iutA gene was $40 \%$ of the tested E. coli isolates, which nearly agree with lopez-banda et al. (2014), $48.1 \%$ the highest prevalence rate of iutA gene was detected by Hussein et al. (2013), Chalmers et al. (2017), and Jørgensen et al. (2019) in 100\%, $93.3 \%$ and $96.9 \%$ of the E. coli isolates, respectively. While Eftekharian et al. (2016), detected iut A gene in $70 \%$ and lopez banda et al. (2014) in 50\% of
E. coli isolates. The virulence gene (traT) detected in $60 \%$ of isolates which nearly to Bok et al. (2020) $54.9 \%$ while $88.8 \%$ and $88.1 \%$ detected by Marwa Hassaen et al. (2020) and Kogovšek et al. (2019). While, $47.7 \%$ detected by Ferreira et al. (2018). Jiménez et al. (2020) determined traT gene in 17 isolates of E.coli 4, from beef, 1 from pork, chicken, wiled fox and 10 from human.

The importance of iss function that allows $E$. coli to avoid host defenses, multiply and distribute, thus promoting the development of the disease (López et al., 2017). The iutA gene is one of the 5 genes of the aerobactin operon. It encodes an outer membrane protein involved in the high-affinity binding of $\mathrm{Fe}+3$ aerobactin and can be plasmid located (Johnson et al., 2006) or chromosomally encoded in some strains (Schouler et al., 2012). The virulence gene (traT) outer membrane protein serum resistance that codifies an outer membrane protein implicated in serum survival, (Johnson \& Stell, 2000), the EXPE constitute (traT) gene more commonly than commensal strains Cyoia et al., 2015. The variation in the presence of virulence encoding genes among different serotypes isolated from different sources revealed that the mechanisms of pathogenesis depends mainly on the presence of different virulence factors not to the different serotypes. (Aranda et al., 2004).

Results obtained showed that marketing meats, especially, minced beef, were contaminated with E.coli strains harboring some virulence genes these findings suggest that, under certain conditions as inappropriate meat handling, consumption of undercooked meat, the possibility exists for retail meat to serve as a vehicle for transmitting pathogenic E.coli to consumers.

\section{CONCLUSION}

Results of this study revealed the presence of E. coli in raw meats and some its products reaching consumers, indicating possible risks of infection to people through the consumption of raw/under-cooked meat or crosscontamination of other food products. Coordinated actions are needed to reduce or eliminate the risks posed by this organism at various stages in food chain. 
2- In addition to the conventional methods used for isolation and identification of E. coli, PCR is required as rapid, accurate and specific tool for detection of pathogenic E. coli and their virulence genes.

\section{REFERENCES}

Abd El-Tawab, A.A.; El-Hofy, I.F.; Nada, M.S. and Deiab, A.A.R. (2015): Detection of virulence genes of enterohaemorrhagic E. coli isolated from some meat products by polymerase chain reaction. Benha Vet. Med. J., 29: 45-52.

Abdul-Raouf, U.M., Ammar, M.S., Beuchat, and L.R., (1996): Isolation of Escherichia coli O157: H7 from some Egyptian foods. International Journal of Food Microbiology 29, 423-426.

Ahmed, N.M. (1992): Incidence and occurrence of Salmonellae and E. coli organisms in packed meat products. $\mathrm{M}$. V. Sc. (Meat Hygiene) Fac. Vet. Med., Assuit University.

Alkeskas, A.; Ogrodzki, P.; Saad, M.; Masood, N.; Rhoma, NR.; Moore, K.; Farbos, A.; Paszkiewicz, K. and Forsythe, S. (2015): The molecular characterisation of Escherichia coli K1 isolated from neonatal nasogastric feeding tubes". BMC Infect Dis. 2015; 15: 449.

"APHA' American Public Health Association (2001): Compendium of Methods for the Microbiological Examination of Foods, 4th Edition. APHA, Washington, DC.

Aranda, K.R.S.; Fagundes-Neto, U. and Scaletsky, I.C.A. (2004): Evaluation of multiplex PCRs for diagnosis of infection with diarrheagenic Escherichia coli and Shigella spp. Journal of Clinical Microbiology, 42: 5849-5853.

Ateba, Cn., and Mbewe, M. (2011): Detection of Escherichia coli o157, 47 virulence genes in isolate from beef, pork, water, human and animal species in the North West province, South Africa. Microbiology vol.126, issue 3 (2011): 240-248.

Barlow, R.S.; Hirst, R.G.; Norton, R.E.; Asshhurst-Smith, $C$. and Bettelheim, K.A. (1999): Novel serotype of enteropathogenic Escherichia coli (EPEC) as a major pathogen in an outbreak of infantile diarrhoea. Journal of Medical Microbiology, 48: 11231125.

Biesalski, H.K. (2005): Meat as a component of a healthy diet. Are there any risks or benefits if meat is avoided in the diet? Meat Science; 70: 509-524.

Bok, E.; Ko 'za A.;' Nska, J.; M-Popczyk, M. Wojciech and Baldy-Chudzik, K. (2020): Extended Phylogeny and Extraintestinal Virulence Potential of Commensal Escherichia coli from Piglets and Sows .Int. J. Environ. Res. Public Health, 17, 366; doi: 10.3390/ijerph17010366.

Buncic, S. (2006): Integrated Food Safety and Veterinary Public Health. CABI International, Oxon, UK. See pp. 3-4, 361-364.

Casey, P. and Condon, S. (2000): Synergistic lethal combination of nitrite and acid $\mathrm{pH}$ on a Verotoxin-negative strain of Escherichia coli O157. International Journal of Food Microbiology, 55: 255258.

Chalmers, G.; Cormier, A.C.; Nadeau, M.; Côté, G.; Reid-Smith, R.J. and Boerlin, $P$. (2017): "Determinants of virulence and of resistance to ceftiofur, gentamycin and spectinomycin in clinical Escherichia coli from broiler chickens in Québec, Canada." Veterinary Microbiology. 203: 149-157.

Cyoia, PS.; Rodrigues, GR.; Nishio, EK.; Medeiros, LP.; Koga, VL.; Pereira, APD.; Vespero, EC.; Houle, S.; Dozois, CM.; Nakazato, G. and Kobayashi, RKT. (2015): Presence of virulence genes and pathogenicity islands in extraintestinal pathogenic Escherichia coli isolates from Brazil. J Infect Dev Ctries; 9(10): 106875.

Darwish, W.S.; Atia, A.S.; El-Ghareeb, W.R. and Elhelaly, A.E. (2018): Prevalence of multidrug resistant shiga toxinproducing Escherichia coli in cattle meat and its contact surfaces. Journal of Food Quality and Hazards Control. 5: 146153.

Duffy, G.; Cagney, H. and Sheridan, J.J. (2003): A Nationwide Surveillance Study on E. coli O157:H7 and Enterobacteriaceae in Irish frozen Beef 
Products. J. Assoc. Anal. Cham, 59: 6780.

Eftekharian, S.; Ghorbanpoor, M.; Shapouri, M.R.S.A.; Ghanbarpour, R.; Jafari, R. and Amani, A. (2016): "Frequency of selected virulence-associated genes in intestinal and extra-intestinal Escherichia coli isolates from chicken." Iranian Journal of Veterinary Medicine. 10(2): 91-96.

Eid, H.M.; El Tabiy, A.A. and Fathy, S.M. (2019): Molecular Characterization of Escherichia Coli Isolated from Meat and Meat Products in Port-Said Markets SCVMJ, XXIV (2), 177-188.

EL-Mossalami, E.I.K. (2003): Risk assessment of ready prepared meat products $\mathrm{Ph}, \mathrm{D}$. Thesis, (Meat Hygiene) Fac. Vet. Med., Cairo Unvi. Egypt.

El-Sherif, A.M. (2009): Different serotypes of E.coli and Salmonellae in some Meat products and their behavior during different heat treatment and cold storage. $\mathrm{Ph}$, D. Thesis Fac. Vet. Med., Cairo. Unvi. Egypt.

Ferreira, J.C.; Filho, R.A.C.P.; Kuaye, A.P.Y.; Andrade, L.N.; Chang, Y. and Darini, A.L.C. (2018): "Virulence potential of commensal multidrug resistant Escherichia coli isolated from poultry in Brazil." Infection, Genetics and Evolution. 65: 251-256.

Fratmico, P.M.; Bhunia, A.K. and Smith, J.L. (2005): Food-borne Pathogens in Microbiology and Molecular Biology, Caister Academic Press, Wymondham, Norfolk, UK, 273.

FSANZ (2013): Agents of foodborne illness, 2nd ed. Food Standards Australia New Zealand,

Canberra.http://www.foodstandards.gov. au/publications/Documents/FSANZ_Foo dborneIllness_2013_WEB.pdf.

Grauke, L.J.; Kudva, I.T.; Yoon, J.W.; Hunt, C.W.; Williams, C.J. and Hovde, C.L. (2002): Gastrointestinal tract location of Escherichia coli O157:H7 in ruminants. Appl. Environ. Microbiol. 68:22692277.

Gyles, CL. (2007): Shiga toxin-producing Escherichia coli: An overview. Journal of Animal Science 85(E Suppl) E45E62.
Hussein, A.H.; Ghanem, I.A.; Eid, A.A.; Ali, M.A.; Sherwood, J.S.; Li, G.; Nolan, L.K. and Logue, C.M. (2013): "Molecular and phenotypic characterization of Escherichia coli isolated from broiler chicken flocks in Egypt." Avian Diseases. 57(3): 602-611.

Ibrahim H.M.; A.H., Reham, A.A., Nesreen, Z.E. and Samma, S.N. (2015): Prevalence of E. coli and detection of virulence genes by multiplex PCR in meat products. Journal Benha veterinary medicine vol.29, No2: 268-273.

Janßen, T.; Schwarz, C.; Preikschat, P.; Voss, M.; Philipp, H.C. and Wieler, L.H. (2001): "Virulence-associated genes in avian pathogenic Escherichia coli (APEC) isolated from internal organs of poultry having died from colibacillosis." International Journal of Medical Microbiology. 291(5): 371-378.

Jeong, Y.; Kim, T.; Kim, J. and Kwon, H. (2012): "Pathotyping avian pathogenic Escherichia coli strains in Korea." Journal of Veterinary Science. 13(2): 145-152.

Jiménez D.D.; Meniño, I.G.; Herrera, A. García, $\quad$ V.; López-Beceiro, A.M.; Alonso, M.P.; Blanco, J. and Mora, A. (2020): Genomic Characterization of Escherichia coli Isolates Belonging to a New Hybrid aEPEC/ExPEC Pathotype O153:H10-A-ST10 eae-beta1 Occurred in Meat, Poultry, Wildlife and Human Diarrheagenic Samples Antibiotics 2020, 9, 192; doi:10.3390/ antibiotics 9040192

Johnson, J.R. and Stell, A.L. (2000): Extended virulence genotypes of Escherichia coli strains from patients with urosepsis in relation to phylogeny and host compromise. J. Infect. Dis., 181, 261272.

Johnson, TJ.; Siek, KE.; Johnson, SJ. and Nolan, LK. (2006): DNA sequence of a ColV plasmid and prevalence of selected plasmid-encoded virulence genes among avian Escherichia coli strains. J Bacteriol; 188: 745-58.

Jørgensen, S.L.; Stegger, M.; Kudirkiene, E.; Lilje, B.; Poulsen, L.L.; Ronco, T.; Dos Santos, T.P.; Kiil, K.; Bisgaard, M.; Pedersen, K.; Nolan, L.K.; Price, L.B.; 
Olsen, R.H.; Andersen, P.S. and Christensen, H. (2019): "Diversity and population overlap between avian and human Escherichia coli belonging to sequence type 95." mSphere. 4(1): e00333-18.

Kaipainen, T.; Pohjanvirta, T.; Shpigel, N.Y.; Shwimmer, A.; Pyörälä, S. and Pelkonen, S. (2002): Virulence factors of $E$. coli isolated from bovine clinical mastitis. Vet. Microbiol. 2002 Feb 26; 85(1): 37-46.

Kaper, J.B. (1994): Molecular pathogenesis of enteropathogenic Escherichia coli. In: Molecular Genetics of Bacterial Pathogenesis (Miller, V.L., Kaper, J.B., Portnoy, D.A. and Isberg, R.R., Eds.), pp. 173-195. ASM Press, Washington, DC.

Karmi, M. (2019): Escherichia coli O157:H7 in Raw and Processed Meat with Virulence Genes Detection in Aswan Governorate. Zag Vet J, Volume 47, Number 3, p. 259-266.

Kimata, K.; Shima, T.; Shimizu, M.; Tanaka, D.; Isobe, J.; Gyobu, Y. (2005): Rapid categorization of pathogenic Escherichia coli by multiplex PCR. Microbiology and Immunology, 49: 485-492.

Kogovšek, P.; Ambrožič-Avguštin, J.; Dovč, A.; Dreo, T.; Hristov, H.; Krapež, U.; Ravnikar, M.; Slavec, B.; Lotrič, M.; Žel, J. and Rojs, O.Z. (2019): "Loopmediated isothermal amplification: rapid molecular detection of virulence genes associated with avian pathogenic Escherichia coli in poultry." Poultry Science. 98(3): 1500-1510.

Lacher, D.W.; Gangiredla, J.; Patel, I.; Elkins, C.A. and Feng, P.CH. (2016): Use of the Escherichia coli identification microarray for characterizing the health risks of Shiga toxin-producing E. coli isolated from foods. J. Food Prot. 79(10):1656-1662.

López-Banda, A.; Erik, M.; Margarita-Leyva; Gabriel-Hoyuela; Ángel H. Hernández; Sara Arroyo-Escalante; David -Barrón, Silvia-Recillas; Juan X-Cortes and Hernández-Castro, $\quad R . \quad$ (2014): Identification of Virulence Factors Genes in Escherichia coli Isolates from Women with Urinary Tract Infection in
Mexico. Bio. Med. Res. Int., |Article ID 959206 | 10 pages | https://doi.org/ 10.1155/2014/959206

López, V.H.M.; Serrano, I.Q.; Delgado, P.D.P.M.; Rodríguez, L.E.V.; OlagueMarchán, M.; Rodríguez, S.H.S.; Luna, M.A.L.; De La Torre A.F. and Santoyo, R.M.R. (2017): "Genes of virulence and phylogenetic group in isolates of avian pathogenic Escherichia coli." Archives of Medicine. 9(6): 1-5.

Marwa Hassan, E.; Mohamed, K. Moursi; Rana, M.A. El-Fattah, and Mohamed, E. Enany (2020): Molecular Detection of Some Virulence Genes of E. Coli Isolated from Broiler Chickens and Ducks at Ismailia Governorate SCVMJ, XXV (1) 1-19.

Michael, P.D. (1991): Escherichia coli O157: $\mathrm{H} 7$ and its significance in foods. International Journal of Food Microbiology, 12(4): 289-301.

Mohammed, M.A.M. (2012): Molecular characterization of diarrheagenic Escherichia coli isolated from meat products sold at Mansoura city, Egypt. Food Control. 25: 159-164.

Navarro-Garcia, F.; Ruiz-Perez, F.; Cataldi, A. and Larzabal, M. (2019): "Type VI secretion system in pathogenic Escherichia coli: structure, role in virulence and acquisition." Frontiers in Microbiology. 10(1965): 1-17.

Nissen, H.; Maugesten, T. and Lea, P. (2001): Survival and growth of Escherichia coli O157:H7, Yersinia enterocolitica and Salmonella enteritidis on decontaminated and untreated meat. Meat Science, 57: 291-298.

Oliveira, E.S.; Cardozo, M.V.; Borzi, M.M.; Borges, C.A.; Guastalli, E.A.L. and Avila, F.A. (2019): "Highly pathogenic and multidrug resistant avian pathogenic Escherichia coli in free-range chickens from Brazil." Brazilian Journal of Poultry Science. 21(1): 1-8.

Ørskov, F. and Ørskov, I. (1992): Escherichia coli serotyping and disease in man and animals. Can. J. Microbiol. 38: 699-704.

Rahal, E.A.; Fadlallah, S.M.; Nassar, F.J.; Kazzi, N. and Matar, G.M. (2015): Approaches to treatment of emerging Shiga toxin-producing Escherichia coli 
infections highlight-ing the O104:H4 serotype. Front Cell. Infect. Microbiol, 5: 24 .

Sallam, KI.; Mohammed, MA.; Ahdy, AM. and Tamura, T. (2013): Prevalence, genetic characterization and virulence genes of sorbitol-fermenting Escherichia coli O157: H- and E. coli O157:H7 isolated from retail beef. Int J Food Microbiol 165:295-301.

Sarowska, J.B.; Futoma, K.; Agnieszka, J.; Kmiecik, M.; Madrzakl, F.; Ksiazczyk, M.; Bugla-Ploskonska, G. and Krol, I.C. (2019): Virulence factors, prevalence and potential transmission of extraintestinal pathogenic Escherichia coli isolated from different sources recent reports. Gut Pathogens, 11:10, 16 p.

Schouler, C.; Schaeffer, B.; Brée, A.; Mora, A.; Dahbi, G. and Biet, F. (2012): "Diagnostic strategy for identifying avian pathogenic Escherichia coli based on four patterns of virulence genes." Journal of Clinical Microbiology. 50(5): 1673- 1678.

Selander, R.K.; Caugant, D.A. and Whittam, T.S. (1987): Genetic structure and variation in natural populations of Escherichia coli, p. 1625-1648. In F. C. Neidhardt, J. L. Ingraham, K.B. Low, B. Magasanik, M. Schaechter, and H. E. Umbarger (ed.), Escherichia coli and Salmonella typhimurium: cellular and molecular biology, vol. 2. American
Society for Microbiology, Washington, D.C.

Seran, T.; Ayşegül, E. and Şahsene, A. (2012): Prevalence of Escherichia coli $\mathrm{O} 157$ in red meat and meat products determined by VIDAS ECPT and Light Cycler PCR. Turk. J. Vet. Anim. Sci., 36(3): 305-310.

Toldrá, Fidel (2010): Handbook of Meat Processing. Blackwell Publishing. ISBN: 978-0-813-82182-5: 481.

Wood, J. (2006): Trends in the organization of the meat industry. pp. 97-104, in: S. Buncic

(Editor). 2006. Integrated Food Safety and Veterinary Public Health. CABI International, CABI International Publishing, Oxon, UK.

Yaguchi, K.; Ogitani, T.; Osawa, R.; Kawano, M.; Kokumai, N.; Kaneshige, T.; Noro,T.; Masubuchi, K. and Shimizu, Y. (2007): Virulence Factors of Avian Pathogenic Escherichia coli Strains Isolated from Chickens with Coli septicemia in Japan. Avian Dis. 2007 Sep; 51(3):656-62.

Zakarya, E.M. and Fouad, M. (2013): Comparison between traditional methods and real time PCR for detection of E. coli in bovine meat products. Assiut Vet. Med. J., 59(138).

Zohreh Mashak (2018): Virulence genes and phenotypic evaluation of antibiotic resistance of vero toxin producing Escherichia coli recovered from milk, meat and vegetables. Jundishapur journal of microbiology 11(5): 262-288.

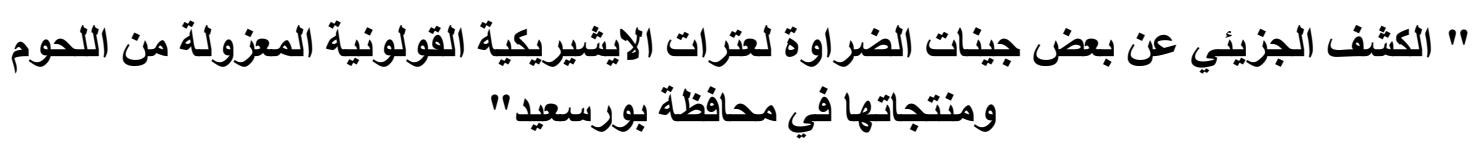

حنان عباس الغياتي ، امل /حد مجاهد ، إيهاب محمود هلال

E-mail: hananelghayaty9866@gmail.com Assiut University web-site: www.aun.edu.eg

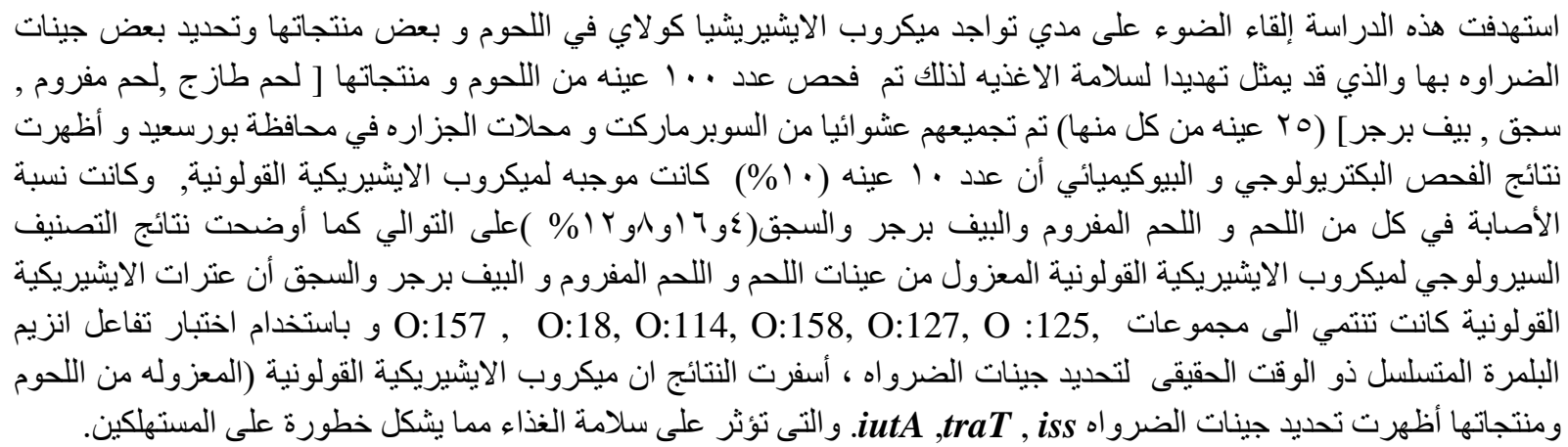

